\title{
PENGARUH KREATIVITAS DAN EFIKASI DIRI TERHADAP NIAT KEWIRAUSAHAAN MAHASISWA FEB UNIVERSITAS TARUMANAGARA
}

\author{
Rio Marden ${ }^{1}$, Nur Hidayah² \\ ${ }^{1}$ Program Studi Manajemen, Fakultas Ekonomi dan Bisnis, Universitas Tarumanagara \\ Email: rio.115170276@stu.untar.ac.id \\ ${ }^{2}$ Program Studi Manajemen, Fakultas Ekonomi dan Bisnis, Universitas Tarumanagara* \\ Email: nurh@fe.untar.ac.id \\ *Penulis Korespondensi
}

Masuk : 02-08-2021, revisi: 15-08-2021, diterima untuk diterbitkan : 30-08-2021

\begin{abstract}
ABSTRAK
Penelitian ini bertujuan untuk mengetahui pengaruh kreativitas dan efikasi diri terhadap niat berwirausaha. Penelitian ini menggunakan metode kuantitatif di mana data yang dikumpulkan oleh peneliti menggunakan metode survey dengan platform "google form" terhadap 100 responden yang merupakan mahasiswa Fakultas Ekonomi dan Bisnis Universitas Tarumanagara. Ada dua hipotesis yang akan diuji dengan cara mengkalkulasi data berskala Likert menggunakan PLS-SEM. Pengambilan sampel dilakukan dengan teknik non-probability sampling. Metode analisis data yang digunakan oleh peneliti adalah PLS-SEM yang dikalkulasi melalui software SmartPLS versi 3.3.3 dengan metode bootstrapping guna mengukur tingkat signifikan. Hasil penelitian menunjukkan terdapat pengaruh positif signifikan kreativitas terhadap niat berwirausaha mahasiswa Fakultas Ekonomi dan Bisnis di Universitas Tarumanagara dan terdapat pengaruh positif signifikan efikasi diri terhadap niat berwirausaha mahasiswa Fakultas Ekonomi dan Bisnis di Universitas Tarumanagara.
\end{abstract}

Kata Kunci: Kreativitas, Efikasi Diri, Niat Kewirausahaan

\section{ABSTRACT}

This study aims to determine the effect of creativity and self-efficacy on entrepreneurial intentions. This study uses a quantitative method where the data collected by the researcher uses a survey method with the "google form" platform on 100 respondents who are students of the Faculty of Economics and Business, Tarumanagara University. There are two hypotheses that will be tested by calculating Likert-scale data using PLS-SEM. Sampling was done by non-probability sampling technique. The data analysis method used by the researcher is PLS-SEM which is calculated through the SmartPLS software version 3.3.3 with the bootstrapping method to measure the level of significance. The results showed that there was a significant positive effect of creativity on the entrepreneurial intentions of students of the Faculty of Economics and Business at Tarumanagara University and there was a significant positive effect of self-efficacy on the entrepreneurial intentions of students of the Faculty of Economics and Business at Tarumanagara University.

Keywords: Creativity, Self-Efficacy, Entrepreneurial Intention

\section{PENDAHULUAN}

\section{Latar Belakang}

Dukungan terhadap kewirausahaan sudah diakui sebagai salah satu bentuk pembangunan sosialekonomi, dikarenakan memiliki target untuk mengurangi tingkat pengangguran, baik di negara maju dan negara berkembang (BarNir et al., 2011; Busenitz et al., 2003; Chou et al., 2011; Mastura dan Abdul Rashid, 2008; Matlay, 2006; Mueller dan Thomas, 2001; VanPraag dan Versloot, 2007). 
Kewirausahaan merupakan proses menciptakan sesuatu hal yang baru dan memiliki nilai dengan mengorbankan waktu dan tenaga yang ada, mengambil risiko, baik itu finansial, fisik, dan juga sosial, serta menerima imbalan moneter dan juga kepuasan serta kebebasan pribadi (Hisrich et.al. dalam Slamet et al., 2014:5). Wirausahawan dapat berkarya dengan bebas terhadap produk atau jasanya sendiri. Kewirausahaan, sebagai sebuah penggerak kegiatan ekonomi, semakin populer sejak itu awal karena memiliki sebuah dampak yang dapat berpengaruh terhadap perkembangan ekonomi daerah tertentu atau negara (Crijns dan Vermeulen, 2007; Karimi et al., 2016).

Kewirausahaan selalu menjadi inti dari pendidikan bisnis (Farooq, 2016). Di masa lalu, faktor sosial-ekonomi telah mengarahkan perencana strategis dan pembuat kebijakan untuk menganggap pengembangan kewirausahaan sebagai elemen penting untuk pertumbuhan dan pembangunan ekonomi (Miralles et al., 2015). Penelitian telah melaporkan bahwa kebijakan yang dipertimbangkan dengan baik dapat berdampak besar dalam memicu perilaku kewirausahaan pada lulusan bisnis baru (Farooq, 2016; Lortie dan Castogiovanni, 2015). Lulusan bisnis diharapkan dapat menciptakan pekerjaan atau layanan baru bagi orang lain dengan memulai usaha bisnis baru (Kolvereid dan Isaksen, 2006; Wilson et al., 2007). Peneliti sering kali mengamati bahwa lulusan bisnis yang memiliki ambisi untuk membangun sebuah usahanya, biasanya akan mencari pekerjaan setelah lulus dari program gelar bisnis dua atau empat tahun (Farooq, 2016).

Kreativitas didefinisikan sebagai proses menghasilkan ide-ide baru dan berguna atau solusi untuk masalah (Amabile et al., 2005). Lingkungan kerja masa depan akan bergantung pada kreativitas pemuda, terutama jika lulusan universitas, untuk menghasilkan nilai ekonomi dan sosial. Kreativitas bertindak sebagai sumber daya kognitif yang dapat memungkinkan orang waspada terhadap lingkungan sekitarnya dan membantu seseorang dapat secara cepat mengenali atau menciptakan peluang (Gielnik et al., 2012). Kreativitas dianggap dapat memberikan dasar kepada individu untuk menciptakan asosiasi baru setiap elemen yang tidak berhubungan sebelumnya, seiring waktu akan dapat menimbulkan penciptaan peluang bisnis baru (Baron, 2008).

Efikasi diri mengacu pada konstrukti motivasi yang terbukti dapat mempengaruhi pilihan aktivitas, tujuan, ketekunan, dan dinamika kerja sebuah bisnis dalam berbagai konteks (Drnovšek et al., 2010; Hmieleski dan Baron, 2009). Efikasi diri dipandang sebagai hal yang penting untuk wirausahawan karena wirausahawan harus yakin dengan kemampuannya dalam melakukan berbagai macam tugas dan terkadang ditemani dengan situasi sulit yang tidak terduga (Baum dan Locke, 2004). Efikasi diri dapat mempengaruhi tingkat usaha dan ketekunan yang dilakukan oleh seseorang dalam melakukan tugas. Efikasi diri juga dapat mempengaruhi pilihan aktivitas dan pengaturan perilaku.

Masa pandemi saat ini tidak sepenuhnya membuat calon wirausahawan menjadi putus asa karena masih ada calon wirausahawan yang berani untuk membangun usahanya sendiri di masa pandemi ini. Calon wirausahawan tentu tidak mengganggap ringan terkait masa pandemi ini, tetapi calon wirausahawan melihat dengan sudut pandang yang berbeda, yaitu calon wirausahawan mengganggap masa pandemi ini merupakan sebuah tantangan bagi calon wirausahawan untuk membuka usahanya sendiri karena calon wirausahawan siap dengan kreativitasnya dan percaya diri bahwa usahanya akan dapat berdiri kokoh di masa pandemi ini. Mahasiswa juga merupakan calon wirausahawan dengan membangun suatu usahanya sendiri. Berdasarkan penjelasan yang ada maka diperlukan penelitian terkait niat berwirausaha yang antara lain dipengaruhi oleh kreatifitas dan efikasi diri. 


\section{Kajian teori}

Penelitian ini menggunakan theory of planned behaviour (TPB) sebagai teori pendukung, untuk menyelidiki niat wirausaha lulusan bisnis baru. Theory of Planned behaviour terdapat tiga penentu niat yang independen secara konseptual. Pertama adalah sikap terhadap perilaku dan mengacu pada seseorang yang memiliki evaluasi atau penilaian yang menguntungkan atau tidak menguntungkan dari perilaku yang bersangkutan. Kedua adalah norma subjektif, yaitu mengcau pada tekanan dari sosial yang dirasakan untuk melakukan atau tidak melakukan perilaku. Ketiga adalah tingkat control perilaku yang mengacu pada kemudahan atau kesulitan yang dirasakan dalam melakukan sebauh perilaku dan diasumsikan mencerminkan pengalaman dari masa lalu serta hambatan ada dapat di antisipasi.

Dell (2008), menjelaskan bahwa "Niat kewirausahaan adalah kecenderungan individu untuk mengekspresikan kinerja kewirausahaan dan mengambil bagian dalam kegiatan yang ditujukan untuk wirausaha". Ozaralli dan Rivenburgh (2016), menjelaskan bahwa "Entrepreneurial intention is the forerunner to be involved in entrepreneurial activities". artinya niat berwirausaha merupakan cikal bakal untuk terlibat dalam kegiatan kewirausahaan. Ismail et. al. (2009), menjelaskan bahwa "potensi individu menuju kewirausahaan terungkap jika ada niat untuk menjadi wirausaha". Krueger (1993), menyatakan bahwa niat berwirausaha mencerminkan komitmen seseorang untuk memulai usaha baru dan merupakan isu sentral yang perlu diperhatikan dalam memahami proses kewirausahaan pendirian usaha baru.

Amabile (1997), menjelaskan bahwa "entrepreneurial creativity as the growth and implementation of unique, distinctive and accurate ideas to launch a new venture". Artinya adalah kreativitas wirausaha sebagai pertumbuhan dan implementasi ide-ide unik, khas dan akurat untuk meluncurkan usaha baru. Guilford (1950), menjelaskan bahwa "Creativity refers to the abilities that are characteristics of creative people", kreativitas mengacu pada kemampuan yang merupakan karakteristik orang kreatif. Munandar (1995), menjelaskan bahwa "kreativitas adalah suatu kemampuan umum untuk menciptakan suatu yang baru, sebagai kemampuan untuk memberikan gagasan-gagasan baru yang dapat diterapkan dalam pemecahan masalah, atau sebagai kemampuan untuk melihat hubungan-hubungan baru antara unsur-unsur yang sudah ada sebelumnya". Hulbeck (1995), menjelaskan bahwa "Creative action is an imposing of one's own whole personality on the environment in an unique and characteristic way". Artinya adalah tindakan kreatif adalah tindakan yang mengesankan memiliki seluruh kepribadian di lingkungan dengan cara yang unik dan khas.

Zampetakis dan Moustakis (2006) menyatakan bahwa studi yang secara khusus membahas tentang hubungan antara kreativitas dan niat berwirausaha, menunjukkan temuan bahwa keluarga yang dipersepsikan mendukung kreativitas meningkat tingkat niat berwirausaha pada pemuda. Hamidi et al. (2008) juga menemukan bahwa kreativitas berpengaruh pada niat kewirausahaan lebih kuat daripada efek dari kontrol perilaku yang dirasakan, norma sosial yang dirasakan, dan kecenderungan mengambil risiko. Zampetakis et al. (2011) menjelaskan bahwa untuk kaum muda yang menganggap dirinya kreatif dan berprestasi lebih tinggi, memiliki niat kewirausahaan dan model peran keluarga tampaknya memberikan pengaruh langsung pada niat kewirausahaannya.

Omrod (2008), menjelaskan bahwa efikasi diri adalah penilaian seseorang tentang kemampuannya sendiri untuk menjalankan perilaku tertentu atau mencapai tujuan tertentu. Laura (2010), menjelaskan bahwa efikasi diri adalah keyakinan seseorang sehingga dapat menguasai suatu situasi dan menghasilkan berbagai hasil yang bernilai positif dan 
bermanfaat. Mujiadi (2003), menjelaskan bahwa efikasi diri merupakan salah satu faktor personal yang menjadi perantara atau mediator dalam interaksi antara faktor perilaku dan factor lingkungan. Bandura (dalam Jess Feist \& Feist, 2010), menjelaskan bahwa efikasi diri keyakinan seseorang dalam kemampuannya untuk melakukan suatu bentuk kontrol terhadap fungsi orang itu sendiri dan kejadian dalam lingkungan. Bandura (1987 dalam Wiryawan, 2013) menyatakan bahwa efikasi diri sebagai kepercayaan seseorang atas kemampuan dirinya untuk menyelesaikan suatu pekerjaan.

Indarti (2008) menyatakan bahwa efikasi diri akan karir seseorang dapat menjadi faktor penting dalam penentuan apakah minat kewirausahaan seseorang sudah terbentuk pada tahapan awal seseorang memulai karirnya. Indarti (2008) juga menjelaskan bahwa efikasi diri merupakan faktor yang penting dalam mempengaruhi intensi kewirausahaan. Rahmi, et al., (2014) menyatakan efikasi diri dibutuhkan untuk mendorong karyawan meyakini kemampuannya dalam mencapai tujuan atau hasil yang diharapkan. Dapat disimpulkan bahwa efikasi diri dapat menumbuhkan niat berwirausaha. Laviolette et al., (2012) menyatakan bahwa efikasi diri kewirausahaan merupakan anteseden kognitif utama dari niat kewirausahaan dan perilaku kewirausahaan.

Berdasarkan penjelasan di atas maka dapat ditarik suatu kerangka berpikir bahwa kreatifitas dan efikasi diri yang ada pada mahasiswa dapat mempengaruhi niat untuk berwirausaha yang digambarkan pada model peneltitian berikut ini:

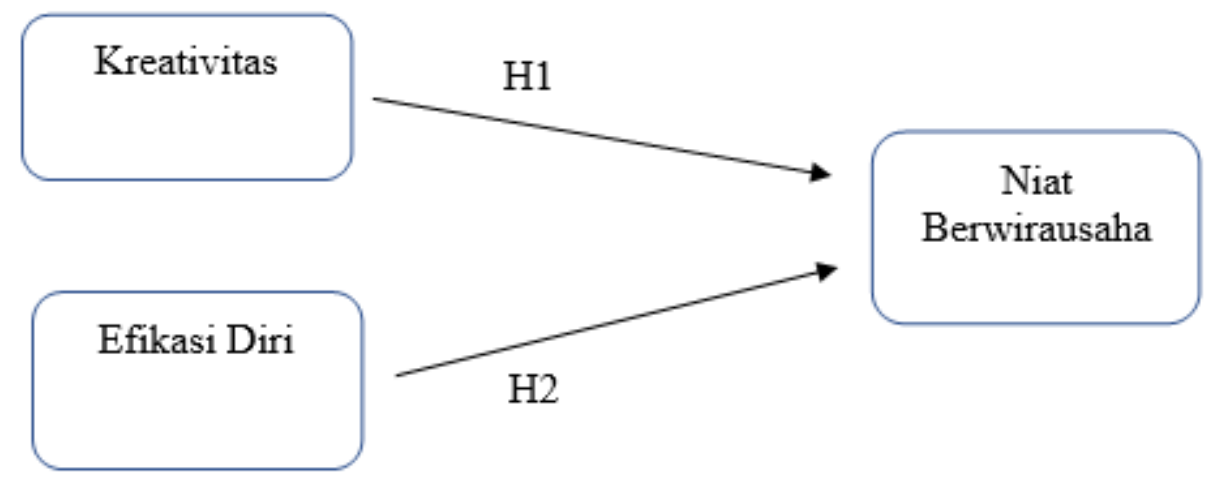

Gambar 1. Kerangka pemikiran

Hipotesisnya dari penelitian ini adalah:

H1: Kreativitas berpengaruh secara positif terhadap niat berwirausaha mahasiswa Fakultas Ekonomi dan Bisnis Universitas Tarumanagara.

H2: Efikasi Diri berpengaruh secara positif terhadap niat berwirausaha mahasiswa Fakultas Ekonomi dan Bisnis Universitas Tarumanagara.

\section{METODE PENELITIAN}

Desain penelitian yang digunakan adalah penelitian konklusif dengan pendekatan deskriptif dengan metode pengumpulan data kuantitatif. Sekaran dan Bougie (2016) menjelaskan bahwa desain penelitian adalah cetak biru atau rencana untuk melakukan pengumpulan, pengukuran, dan analisis data, dibuat untuk menjawab pertanyaan yang terkait terhadap penelitian. Kuncoro (2009) menyatakan bahwa penelitian konklusif (conclusive research) adalah penelitian yang bertujuan untuk menguji atau membuktikan sesuatu dan untuk membantu peneliti dalam memilih tindakan khusus selanjutnya. Populasi dalam penelitian ini adalah mahasiswa Fakultas Ekonomi dan Bisnis di Universitas Tarumanagara. Penelitian ini menggunakan teknik nonprobability 
sampling untuk mahasiswa Fakultas Ekonomi dan Bisnis Universitas Tarumanagara. Pengambilan sampel dalam penelitian ini dilakukan pada mahasiswa Fakultas Ekonomi dan Bisnis di Universitas Tarumanagara dengan jumlah sampel sebanyak 100 responden dengan menyebarkan angket kepada mahasiswa. Responden yang digunakan sebanyak 100, 52 orang $52 \%$ mahasiswa sisanya $48 \%$ mahasiswi, responden yang berasal dari jurusan manajemen sebanyak 97 orang atau 97\%, sisanya 3\% dari jurusan akuntansi. Angkatan 2017/2018 sebanyak 50 atau 50\% sisanya dari angkatan lain yang masih aktif kuliah, kemudian usia responden berusia yang berada antara 20-21 tahun sebanyak 53 atau 53\%, latar belakang pekerjaan orang tua yang berwirausaha sebayak 70 responden latar atau $70 \%$.

Pengumpulan data dilakukan dengan menggunakan kuesioner yang diberi skor 1-5 berupa skala likert. Data dianalisis menggunakan PLS-SEM dimana data diolah dengan menggunakan software SmartPLS 3. Pertama, dilakukan pengolahan data outer model untuk menguji validitas dan reliabilitas. Uji validitas dapat dilihat dari nilai outer loadings $>0,5$ dan nilai Average Variance Extracted $>0,5$. Selanjutnya dilakukan validitas diskriminan dengan melihat nilai Cross Loading yang diacu pada nilai outer loadings pada masing-masing indicator terhadap variabel latennya sendiri. Uji reliabilitas dapat dilihat dari besarnya nilai Cronbach's Alpha dengan minimal diatas 0,7 sehingga data yang digunakan dapat diklaim memiliki reliabilitas. Kedua, dilakukan pengolahan pada inner model untuk menguji hipotesis yang telah dihasilkan. Langkah pertama dalam menguji hipotesis yaitu menguji konstruk penelitian dengan melihat nilai $\mathrm{R}$-Square dengan kriteria jika nilai $\mathrm{R}^{2}$ sebesar 0,75 dapat dikatakan substansial, nilai $\mathrm{R}^{2}$ sebesar 0,50 dapat dikatakan sedang, dan nilai $\mathrm{R}^{2}$ sebesar 0,25 dapat dikatakan lemah. Effect size memiliki 3 nilai interpretasi yaitu 0,02 menandakan bahwa variabel independent memiliki pengaruh kecil, 0,15 memiliki pengaruh sedang, dan 0,35 memiliki pengaruh yang kuat. Nilai Predictive Relevance dapat dikatakan baik jika suatu model dapat dinyatakan memiliki predictive relevance jika nilai Q2 >0. Nilai GoF (Goodness of Fit) dengan kriteria jika nilai Goodness of Fit sebesar 0,1 maka nilai tersebut dikatakan nilai kecil, 0,25 untuk nilai sedang, dan 0,36 untuk nilai besar. Selanjutnya dilakukan pengujian hipotesis, untuk melihat prediksi yang terjadi dapat dilihat nilai yang dihasilkan apakah koefisien (original sample) tersebut positif atau negatif, dan menggunakan $t$-statistic dengan kriteria jika nilai $t$-statistic 1,96 (tingkat signifikansi $=5$ persen $)$.

Variabel dan jumlah pernyataan yang digunakan serta data yang akan diolah dalam penelitian ini disajikan pada Tabel 1 di bawah ini:

Tabel 1. Konstruksi Penelitian

\begin{tabular}{|c|c|c|c|}
\hline No & Variabel & Item & Sumber \\
\hline 1 & Kreativitas & 7 & Tierney dan Farmer's (2002), Gong et al., (2003), dan Zhou dan \\
George (2001)
\end{tabular}

\section{Hasil Analisis Data}

Hasil validitas diperoleh semua angka pada setiap pernyataan $>0,5$ pada nilai Outer Loadings untuk setiap pernyataan, dan diperoleh semua angka $>0,5$ pada nilai Average Variance Extracted maka semua pernyataan dan variabel yang digunakan adalah valid. Cross Loadings memiliki nilai yang dihasilkan antar indikator variabel laten itu sendiri lebih besar dari nilai yang dihasilkan antar indikator variabel laten lainnya. 
Hasil reliabilitas, maka berdasarkan hasil yang dihitung dengan program SmartPLS 3. semua angka pada nilai Cronbach's Alpha untuk setiap pernyataan $>0,7$. Sehingga pernyataan yang digunakan dalam penelitian ini reliabel berdasarkan dua nilai reliabilitas yaitu Cronbach's Alpha dan Composite Reliability.

Hasil nilai $r$-square adjuted dari variabel kreativitas dan efikasi diri merupakan prediktor yang lemah dalam mempengaruhi niat kewirausahaan. Nilai koefisien determinasi yang dihasilkan adalah 40,8\%, yang artinya variabel niat kewirausahaan dipengaruhi oleh kreativitas dan efikasi diri sebesar 40,8\% dan sisanya sebesar 59,2\% dijelaskan oleh variabel lain yang tidak dimasukkan pada penelitian ini.

Path Coefficient adalah hal yang penting dalam penelitian untuk menyimpulkan hasil akhir sebuah olahan data yang berasal dari tanggapan responden. Hasil nilai path coefficient dilakukan agar dapat mengetahui petunjuk tingkat dari signifikansi yang dimiliki oleh sebuah model penelitian atau pengujian hipotesis. Berikut hasil perhitungan path coefficients dan bootstrapping.

Tabel 2. Hasil Path Coefficient

\begin{tabular}{|c|c|c|c|c|c|}
\hline Hipotesis & Hipotesis & Original Sample & t-statistic & p-values & Kesimpulan \\
\hline H1 & $\begin{array}{c}\text { Kreativitas } \rightarrow \text { Niat } \\
\text { Kewirausahaan }\end{array}$ & 0,438 & 3,995 & 0,000 & Diterima \\
\hline H2 & $\begin{array}{c}\text { Efikasi Diri } \rightarrow \text { Niat } \\
\text { Kewirausahaan }\end{array}$ & 0,256 & 2,153 & 0,016 & Diterima \\
\hline
\end{tabular}

Hasil nilai effect size menunjukkan bahwa pada efikasi diri memiliki pengaruh kecil terhadap niat kewirausahaan dengan nilai interpensi 0,053. Kreativitas memiliki pengaruh sedang terhadap niat kewirausahaan dengan nilai interpensi 0,156 .

Hasil nilai Predictive Relevance menunjukkan bahwa niat berwirausaha memiliki nilai lebih dari 0 yaitu dengan nilai 0,195 , nilai ini merupakan nilai observasi dan estimasi parameter variabel adalah baik.

Hasil nilai GoF diatas menunjukkan oleh nilai sebesar 0,469 yang artinya adalah nilai GoF yang dihasilkan diatas 0,36 sehingga dapat disebut bahwa nilai GoF yang dihasilkan adalah nilai besar.

\section{HASIL DAN PEMBAHASAN}

\section{Diskusi}

Hipotesis pertama menyatakan bahwa kreativitas berpengaruh positif yang signifikan terhadap niat berwirausaha. Hasil penelitian ini sejalan dengan penelitian Gielnik et al., (2012) menyatakan bahwa para sarjana bertindak kreativitas sebagai sumber daya kognitif yang memungkinkan orang untuk waspada tentang lingkungan mereka dan membantu mereka secara aktif mengenali atau menciptakan peluang Hal ini juga sesuai dengan kasus kewirausahaan menurut Liñán et al. (2011); Lee dan Wong, (2004); Ma dan Tan, (2006), di mana kreativitas dianggap memberikan dasar kepada individu untuk menciptakan asosiasi baru antara elemenelemen yang sebelumnya tidak berhubungan, pada gilirannya menimbulkan pengakuan dan penciptaan peluang bisnis baru (Baron, 2008). Frese dan Gielnik, (2014) juga menyatakan para sarjana telah mengeksplorasi hubungan antara kreativitas dan kewirausahaan. Hansen et al., (2011), telah menguji model multidimensi pengenalan peluang di mana kreativitas merupakan komponen penting. Lee dan Wong, (2004) juga menjelaskan bahwa orang-orang kreatif, lebih 
cenderung tertarik pada peluang kerja yang memungkinkan mereka mengembangkan potensi kreatif mereka, dan lebih cenderung menggunakan keterampilan mereka untuk memanfaatkan ide-ide bisnis yang baik dibandingkan dengan orang yang kurang kreatif. Mahasiswa Fakultas Ekonomi dan Bisnis Universitas Tarumanagara memiliki ide-ide yang kreatif untuk menjadi bekal dalam membangun usahanya sendiri untuk dimasa yang akan datang, sehingga akan menggunakan ketrampilan yang dimiliki untuk terus berpikir kreatif dan inovatif.

Hipotesis kedua menyatakan bahwa efikasi diri berpengaruh positif yang signifikan terhadap niat berwirausaha. Hasil penelitian ini sejalan dengan penelitian penelitian Baum dan Locke, (2004) dalam literatur yang menyoroti anteseden dari niat kewirausahaan, efikasi diri dipandang sebagai hal yang penting bagi wirausahawan karena mereka harus yakin dengan kemampuan mereka untuk melakukan tugas yang berbeda dan seringkali tidak diantisipasi dalam situasi yang tidak pasti. Efikasi diri dianggap mempengaruhi tidak hanya pada tingkat usaha dan ketekunan yang dilakukan seseorang dalam tugas tertentu, tetapi juga pilihan aktivitas dan pengaturan perilaku. Chen et al. (1998) menjelaskan bahwa sehubungan dengan penelitian sebelumnya yang telah memperlakukan efikasi diri kewirausahaan sebagai anteseden niat, yaitu, sebagai variabel yang dapat membedakan pengusaha dari non-pengusaha. Hendra. W (2014), juga memiliki hasil penelitian yang sama yaitu Efikasi diri merupakan kondisi dimana individu percaya bahwa penilaku untuk berwirausaha mudah atau dapat dilakukan. Efikasi diri memiliki peran terhadap niat berwirausaha mahasiswa, semakin tinggi nasa percaya diri mahasiswa dan kematangan mentalnya maka semakin tinggi perannya untuk membangkitkan niat berwirausaha mahasiswa. Hasil penelitian ini membuktikan bahwa efikasi diri berpengaruh positif dan signifikan terhadap niat berwirausaha. Drnovšek et al. (2010) juga menjelaskan bahwa untuk peran dari efikasi diri dalam niat kewirausahaan pembentukan, atau yang telah menempatkan penekanan pada kecerdasan emosi diri pada sikap kewirausahaan. Mahasiswa Fakultas Ekonomi dan Bisnis Universitas Tarumanagara masih memiliki kepercayaan diri dan semangat untuk membangun usahanya sendiri dengan niat berwirausaha walaupun dalam kondisi pandemi saat ini

\section{KESIMPULAN DAN SARAN}

Terdapat dua kesimpulan dari penelitian ini, yaitu: pertama, terdapat pengaruh yang signifikan dari variabel kreativitas terhadap niat berwirausaha mahasiswa Fakultas Ekonomi dan Bisnis di Universitas Tarumanagara. Kedua, terdapat pengaruh yang signifikan variabel efikasi diri terhadap niat berwirausaha mahasiswa Fakultas Ekonomi dan Bisnis di Universitas Tarumanagara. Penelitian ini memberikan saran bagi peneliti selanjutnya untuk meningkatkan jumlah variabel independen yang berpotensi dapat mempengaruhi niat berwirausaha, seperti daya inovasi, dukungan pendidikan, komitmen wirausaha, dan lain-lain. Peneliti selanjutnya juga disarankan untuk untuk mengambil sampel lebih banyak dan berasal dari mahasiswa Fakultas ekonomi dan bisnis dari beberapa universitas. Bagi pihak mahasiswa yang ingin berwirausaha, seharusnya mengembangkan potensi kreativitas yang dimiliki dan memanfaatkannya untuk ideide bisnis sehingga menciptakan usaha yang berbeda dari yang belum pernah ada sebelumnya. Efikasi diri mahasiswa perlu ditingkatkan agar mahasiswa memiliki keyakinan yang lebih besar sehingga dapat meningkatkan niat untuk berwirausaha bagi pihak praktisi pendidikan, penelitian ini dapat digunakan sebagai masukan dalam mengembangkan pembelajaran kewirausahaan yang mengaitkan kreativitas dan efikasi diri dengan niat berwirausaha.

\section{REFERENSI}

Aamir, H., Imran, S., Imran, A., \& Syed, A. H. (2020). Entrepreneurial intention of Indian university students: the role of opportunity recognition and entrepreneurship education. Education + Training. 
Ajzen. I. (2002). Perceived Behavioral Control, Self-Efficacy, Locus of Control, and the Theory of Planned Behaviour. Journal of Applied Social Psychology, 1-20.

Ana, P. R., Filipa, E. J., Carlos, A. P., \& Patrícia, A. (2019). The contribution of emotional intelligence and spirituality in understanding creativity and entreprenurial intention of higher education students. Education + Training.

Bandura, A. (1994). Self-Efficacy. Encyclopedia of human behaviour, Vol. 4, 71-81.

Benedetta, B., Veronica, M., \& Michela, L. (2017). The power of peers: A new look at the impact of crreativity, social context and self-efficacy on entrepreneurial intentions. International Journal of Entrepreneurial Behaviour \& Research.

Betram, D. (n.d.). Likert Scales. ACADEMIA.

Chiayu, T., \& Suechin, Y. (2013). The Role of Entrepreneurial Creativity in Entrepreneurial Processes. International Journal of Innovation, Management and Technology, Vol. 4, No.2.

Ghozali, I. (2014). Structural Equation Modeling Metode Alternatif dengan Partial Least Square.

Han, G. H., \& Bai, Y. (2020). Leaders can facilitate creativity: the moderating roles of leader dialectical thinking and LMX on employee creative self-efficacy and creativity.

Jin, Y., Hefu, L., \& Jibao, G. (2017). A multi-level study of servant leadership on creativity: the roles of self-efficacy and power distance. Leadership \& Organization Development Journal, Vol 38(Issue 5).

Joe, F. H., Christian, M. R., \& Marko, S. (2011). PLS-SEM: Indeed A Silver Bullet. Journal of Marketing Theroy and Practice, Vol. 19, No. 2, 139-151.

Peterson, M., Mueller, S. L., McGee, J. E., \& Sequeira, J. M. (2009). Entrepreneurial SelfEfficacy: Refining the Measure.

Roya, M., Mohammad, R. Z., Mohhammad, H. M., \& Jahngir, Y. F. (2014). The impact of entrepreneurial ideas and cognitive style on students entrepreneurial intention. Journal of Entrepreneurship of Emerging Economies, Vol. 6, No. 2, 140-162.

Sekaran, U., \& Bougie, R. (2016). Research methods for business: a skill-building approach. United Kingdom: Wiley.

Shahab, Y., Chengang, Y., Arbizu, A. D., \& Haider, M. J. (2018). Entrepreneurial self-efficacy and intention: do entrepreneurial creativtiy and education matter? International Journal of Entrepreneurial Behaviour \& Research.

Smith, R. M., Sardeshmukh, S. R., \& Combs, G. M. (2016). Understanding Gender, Creativity, and Entrepreneurial Intentions. Education + Training, Vol. 58, No. 3, 263-282.

Suphat Sukamolson, P. (n.d.). Fundamentals of quantitative research. Language Institute.

Swati, M., \& Rajib, L. D. (2015). Transformational leadership and employee creativity: mediating role of creative self-efficacy and moderating role of knowledge sharing. Management Desicion, Vol 53(Issue: 5), 894-910.

Tenenhaus, M., Amato, S., \& Esposito, V. V. (2004, June). A global goodness-of-fit index for PLS structural equation modelling. Proceedings of the XLII SIS scientific meeting, Vol. 1, No. 2, 739-742.

Thundiyil, T. G., Chiaburu, D. S., Li, N., \& Wagner, D. T. (2016). Joint effects of creative selfefficacy, positive and negative effect on creative performance. Chinese Management Studies, Vol 10, No.4, 726-745.

Timothy, O. A., Mujidat, O. B., Kahilu, K.-S., Olaitan, W. O., \& Rachel, L. (2020). Entrepreneurial intentions of real estate students: an ordinal analysis of the predictors. Journal of Facilities Management.

Wetzels, M., Odekerken-Schröder, G., \& Van, O. C. (2009). Using PLS path modeling for assessing hierarchical construct models: Guidelines and empirical illustrarion. MIS quarterly, 177-195. 
Wirayawan, Z. Z., \& Hidayah, N. (2013). Pengaruh Motivasi, Norma Subyektif dan Efikasi Diri terhadap Niat Melakukan Penjualan pada Tenaga Penjual di Beberapa Mall Jakarta. Karya Ilmiah Dosen, 5-47.

Wiyanto, H. (2014). Pengaruh Efikasi Diri dan Lingkungan Terhadap Niat Berwirausaha (Studi Pada Mahasiswa Program Studi Manajemen Fakultas Ekonomi Universitas Tarumanagara. Jurnal Manajemen, 18, No. 1, 114-129. 